\title{
Photosynthetic Characteristics of Melons Grown under High Temperatures
}

\author{
Niramit Kitroongruang, Shuichiro Jodo, Junya Hisai and Masahiro Kato \\ College of Agriculture, Ehime University, Matsuyama 790
}

\begin{abstract}
Summary
Diurnal changes in photosynthesis and transpiration in melons were examined, using ' $9-8$ ' and 'Thai-7' lines and 'Ogon-makuwa' and 'Perlita' along with some of their hybrids. Variations were found in both photosynthetic and transpiration rates among the genotypes, and there was a tendency for the genotypes with higher photosynthetic rates to have higher transpiration rates. When the melon plants were stressed by exposing them to temperatures of $50^{\circ} \mathrm{C}$ for $30 \mathrm{~min}$ and $48^{\circ} \mathrm{C}$ for $60 \mathrm{~min}$ on 2 different dates, the stress resulted in a decrease in photosynthetic rates but not in transpiration rates of the melon leaves. This indicates the significance of mesophyll, not stomatal, resistance to photosynthesis. The photosynthetic rates of ' $9-8$ ' line and its hybrids were less affected by the heat stress, suggesting the line's heattolerant potential and its heritability. Photosynthetic rates after heat stress did not correspond well with electrolyte leakage data. Since correlations between photosynthesis and a) leaf chlorophyll and b) nitrogen content were significant, high leaf chlorophyll and nitrogen content along with less-reduced photosynthetic rates after heat stress can possibly be used as indicators in selecting melon for high photosynthetic capacity under high temperature.
\end{abstract}

\section{Introduction}

Although muskmelon thrives best and develops the highest flavor in a hot, dry climate, most cultivars have been improved for use in areas with a rather cool summer (Thompson and Kelly, 1957; Whitaker and Davis, 1962). In tropical countries, therefore, growing muskmelon introduced from abroad is practically limited to the cool-dry season because high temperature and rain promote the infestation of various kinds of pathogens. Otherwise, growing muskmelon under a shelter, such as plastic or vinyl house, is a must. But the afternoon temperature in such houses can easily rise above optimum point for muskmelon growth (Jun et al., 1986) so that there is a need to develop heattolerant muskmelon for such conditions.

Superoptimal temperature can cause damage to melon at various developmental stages. The inhibition of seed germination and seedling growth (Kadota, 1959), depression of female flower expression (Kamiya and Tamura, 1962), failure of fertilization, and reduction of fruit growth and sugar accumulation (Suzuki and Masuda, 1961) are some adverse effects. The basic mechanism(s) of heat

Received for publication 5 July 1991. tolerance is unknown, but efforts have been made to correlate the stability of cell membrane (Tai and Shannon, 1983) and heat shock protein (Cooper and Ho, 1983; Meyer and Chartier, 1983) after heat stress to heat tolerance. However, since the reduction of photosynthesis at superoptimal temperature is well understood (Pearcy et al., 1977), our objectives were to 1 ) investigate photosynthetic characteristics of some potential heat-tolerant melon lines and 2) analyze photosynthetic responses of these melons to high temperatures.

\section{Materials and Methods}

\section{Plant materials and growing conditions}

Two melon lines, '9-8' and 'Thai-7', 'Ogonmakuwa', 'Perlita', the hybrids between ' $9-8$ ' and the rest, and 'Thai- 7 ' $\times$ 'Perlita' were used in this study (Table 1). '9-8' was selected from a cross between 'MS II' line and 'Earl's Favourite' for its strong growth habit, fruit setting ability, powdery mildew resistance, and fruit soluble solids content, compared with 'Earl's Tokai R220' (a summerseason cultivar) (Bhattacharya et al., 1970; Jodo and Kato, 1989). Because the selections were made on the basis of performance in a glasshouse during the summer, we speculated that ' $9-8$ ' might 
have heat-tolerance capacity. 'Thai- 7 ' is a land race grown throughout northern Thailand in the rainy season. 'Ogon-makuwa' is a Japanese melon. 'Perlita' is a commercial cultivar widely grown in western U.S.A. The seeds were sown individually in small plastic pots on 6 April 1990. Seeedlings were transplanted into plastic baskets $(40 \times 60 \times 15 \mathrm{~cm})$ filled with a $3: 1$ mixture of sandy soil and leaf mold on 12 May 1990, and placed in a vinyl house. Each basket contained 2 plants; and there were 8 plants for each line and cultivar. Standard practices for growing melon in Japan were followed.

\section{Items of examination}

(1) On 10 July, photosynthesis and transpiration were measured at intervals from morning to evening to elucidate genotypic differences among the varieties and the hybrids.

(2) Physiological responses to high temperature treatment among the varieties and the hybrids were measured on 21 July 1990, by closing the vinyl house and allowing the air temperature to rise to $50^{\circ} \mathrm{C}$ for $30 \mathrm{~min}(11: 30-12: 00 \mathrm{hr})$. On this date most of the melons were at the early fruit setting stage. Photosynthesis and transpiration were measured and leaf samples for conductivity test of electrolyte leakage were taken before and after the heat treatment. Since the electrolyte leakage data did not correspond well with the photosynthetic rates, the second heat treatment was applied to the melons on 24 July. However, we were able to raise the temperature inside the house to $48^{\circ} \mathrm{C}$ only; and for that reason we extended the treatment time to $60 \mathrm{~min}$. During the treatments, both air and leaf temperatures were measured with thermal sensors connected to a data logger (Model DL1200, NE Sanei, Japan), thus the similarity between air and leaf temperatures was assured. Furthermore, since the relative humidity in the house approached $100 \%$, the transpirational cooling effect should have been minimal. Photosynthesis was measured when the temperature inside the house became normal, about $30 \mathrm{~min}$ after the vinyl house was reopened.

(3) Relationship between photosynthetic rates and related leaf characteristics, i.e., transpiration, specific dry weight, and chlorophyll and nitrogen contents, were examined. The purpose was to attempt to correlate a parameter with heat-tolerance in melon.

\section{Measurements of photosynthesis and related characteristics}

Photosynthesis and transpiration of fully expanded leaves were simultaneously measured with a portable gas analyzer (Model LCA-2, ADC Co., England). The analyzing time was 1 min per sample. Since the analyzer was equipped with a light sensor, the data obtained under insufficient light were discarded. However, the variation in light intensity was allowed to fluctuate within $10 \%$ of means in each plot. All the leaves used for measurements were facing south, approximately $80 \mathrm{~cm}$ above the ground (the 18th to 24th leaf, according to genotypes). Different plants were used for measurements on different dates. After measuring photosynthesis, acetone-extracted leaf chlorophyll contents were analyzed with Beckman spectrophotometer (Model DU-65) at the wavelengths of $440.5,622$, and $644 \mathrm{~nm}$, according to Nybom (1955). Leaf nitrogen content was analyzed with Sumigraph (Model NC-80, Sumitomo Chem. Ind. Co.). Leaf samples for the conductivity test of electrolyte leakage were taken before and after heat treatments. The conductivity test was that described by Onwueme (1979). Leaf discs of $2 \mathrm{~cm}$ in diameter were cut and immersed in $10 \mathrm{ml}$ of double distilled deionized water in a bottle, infiltrated under vacuum and shaken for $1 \mathrm{hr}$. The electrical conductance $\left(R_{1}\right)$ of the liquid in each bottle was measured with a conductivity bridge (TOA, Co., Japan). The samples were then frozen at $-70^{\circ} \mathrm{C}$ to kill the tissue. After warming to room temperature and shaken for $1 \mathrm{hr}$, the conductance $\left(\mathrm{R}_{2}\right)$ was remeasured. The ratio of the two readings $\left(R_{1} / R_{2}\right)$ was used as a measure of the relative injury. For photosynthetic and transpiration rates, measurements were made on 3 to 5 plants. For other characteristics and conductivity test, samples were taken from each plant.

\section{Results and Discussion}

\section{Diurnal changes in photosynthesis and transpi- ration}

Differences in average photosynthetic rates among the parents and their hybrids at different times within a day were highly significant (Table 1). Differences in the corresponding average tran- 
spiration rate were also significant (Table 2). 'Perlita' and ' $9-8$ ' had about the same photosynthetic rates at $23 \mathrm{mgCO}_{2} \cdot \mathrm{dm}^{-2} \cdot \mathrm{hr}^{-1}$, but ' $9-8$ ' transpired significantly less than did 'Perlita'. 'Thai-7' and 'Ogon-makuwa' had lowest photosynthetic and transpiration rates, ranging between 17 to $19 \mathrm{mgCO} \cdot \mathrm{dm}^{-2} \cdot \mathrm{hr}^{-1}$ and between 9 to $10 \mathrm{gH}_{2} \mathrm{O} \cdot \mathrm{dm}^{-2} \cdot \mathrm{hr}^{-1}$, respectively. All $\mathrm{F}_{1}$ hybrids except 'Thai- 7 ' $\times$ 'Perlita' performed as well as the superior parents, both photosynthetically and transpirationally, thus exhibiting heterosis with respect to these physiological processes. In general, an increase in temperature increases transpiration rates and raises the $\mathrm{CO}_{2}$ compensation point (Bar-Tsur et al., 1985). However, the diurnal changes in photosynthetic rates within each genotype in this study and those reported by Fukuyama et al., (1986) seem to result mainly from variations in intensity of photosynthetically active radiation (PAR) rather than from those of temperature. The PAR increased from $798 \mu \mathrm{mol} \cdot \mathrm{m}^{-2} \cdot \mathrm{sec}^{-1}$ at $8.30 \mathrm{hr}$ to about $1,200 \mu \mathrm{mol} \cdot \mathrm{m}^{-2} \cdot \mathrm{sec}^{-1}$ around noon before it gradually decreased to $493 \mu \mathrm{mol} \cdot \mathrm{m}^{-2} \cdot \mathrm{sec}^{-1}$ at $16.30 \mathrm{hr}$; the temperatures did not vary much, ranging from $28.4^{\circ} \mathrm{C}$ in the morning to $31.9^{\circ} \mathrm{C}$ in the afternoon (Table 2). The photosynthetic rate of $\mathrm{C}_{3}$ plants generally is not inhibited at temperatures lower than $35^{\circ} \mathrm{C}$ (Larcher, 1980); our preliminary study (unpublished data) showed that photosynthesis of all the melons tested started to decrease at a temperature above $35^{\circ} \mathrm{C}$.

Table 1. Varietal difference and time course variation in photosynthesis $\left(\mathrm{mgCO}_{2} \cdot \mathrm{dm}^{-2} \cdot \mathrm{hr}^{-1}\right)$ in melons measured on 10 July 1990 .

\begin{tabular}{|c|c|c|c|c|c|c|c|c|}
\hline \multirow[b]{2}{*}{ Variety/cross } & \multicolumn{7}{|c|}{ Time $/\left(\mathrm{PAR}, \mu \mathrm{mol} \cdot \mathrm{m}^{-2} \cdot \mathrm{sec}^{-1}\right)$} & \multirow[b]{2}{*}{ Mean $^{2}$} \\
\hline & $\begin{array}{c}8: 30 \\
(798)\end{array}$ & $\begin{array}{c}9: 30 \\
(961)\end{array}$ & $\begin{array}{c}11: 30 \\
(1182)\end{array}$ & $\begin{array}{c}13: 30 \\
(1179)\end{array}$ & $\begin{array}{c}14: 30 \\
(1064)\end{array}$ & $\begin{array}{l}15: 30 \\
(934)\end{array}$ & $\begin{array}{l}16: 30 \\
(493)\end{array}$ & \\
\hline '9-8' & 22.0 & 24.4 & 26.8 & 28.1 & 28.2 & 22.8 & 12.7 & $23.5 \mathrm{a}$ \\
\hline 'Thai-7' (T) & 16.0 & 20.4 & 19.0 & 19.3 & 17.0 & 17.2 & 9.6 & $16.9 \mathrm{c}$ \\
\hline 'Ogon-makuwa' $(O)$ & 16.5 & 21.7 & 25.0 & 22.0 & 18.7 & 17.1 & 11.2 & $18.9 \mathrm{~b}$ \\
\hline 'Perlita' (P) & 22.0 & 24.8 & 29.0 & 26.4 & 25.5 & 19.9 & 15.1 & $23.2 \mathrm{a}$ \\
\hline$' 9-8 ' \times T$ & 21.1 & 23.9 & 25.9 & 24.9 & 23.3 & 21.0 & 15.1 & $22.1 \mathrm{a}$ \\
\hline$' 9-8 ’ \times 0$ & 21.4 & 26.5 & 27.0 & 26.4 & 22.3 & 21.6 & 10.2 & $22.2 \mathrm{a}$ \\
\hline $9-8^{\prime} \times P$ & 21.7 & 23.4 & 26.9 & 27.1 & 21.3 & 22.7 & 14.0 & $22.4 \mathrm{a}$ \\
\hline$T \times P$ & 16.9 & 23.5 & 24.8 & 23.5 & 21.0 & 20.0 & 12.2 & $20.2 \mathrm{~b}$ \\
\hline $\operatorname{Mean}^{z}$ & $19.7 \mathrm{~d}$ & $23.6 \mathrm{~b}$ & 25.6 a & $24.7 \mathrm{ab}$ & $22.2 \mathrm{c}$ & $20.3 \mathrm{~d}$ & $12.5 \mathrm{e}$ & \\
\hline
\end{tabular}

PAR: Photosynthetically active radiation.

¿ Mean separation within column (or row) by Duncan's multiple range test, $5 \%$ level.

Table 2. Varietal difference and time course variation in transpiration $\left(\mathrm{gH}_{2} \mathrm{O} \cdot \mathrm{dm}^{-2} \cdot \mathrm{hr}^{-1}\right)$ in melons measured on 10 July 1990

\begin{tabular}{|c|c|c|c|c|c|c|c|c|}
\hline \multirow[b]{2}{*}{ Variety/cross } & \multicolumn{6}{|c|}{ Time/(Leaf temperature, ${ }^{\circ} \mathrm{C}$ ) } & \multirow[b]{2}{*}{$\begin{array}{l}16: 30 \\
(30.4)\end{array}$} & \multirow[b]{2}{*}{ Mean $^{2}$} \\
\hline & $\begin{array}{c}8: 30 \\
(28.4)\end{array}$ & $\begin{array}{c}9: 30 \\
(29.8)\end{array}$ & $\begin{array}{l}11: 30 \\
(30.8)\end{array}$ & $\begin{array}{l}13: 30 \\
(31.9)\end{array}$ & $\begin{array}{l}14: 30 \\
(31.4)\end{array}$ & $\begin{array}{l}15: 30 \\
(32.4)\end{array}$ & & \\
\hline '9-8' & 9.7 & 10.4 & 9.0 & 12.0 & 11.9 & 12.1 & 10.5 & $10.8 \mathrm{bc}$ \\
\hline 'Thai-7’ (T) & 8.0 & 9.0 & 7.0 & 9.8 & 9.1 & 9.8 & 7.6 & $8.6 \mathrm{~d}$ \\
\hline 'Ogon-makuwa' $(\mathrm{O})$ & 9.2 & 10.9 & 11.5 & 11.6 & 10.6 & 10.0 & 8.9 & $10.4 \mathrm{c}$ \\
\hline 'Perlita' (P) & 10.3 & 11.2 & 11.8 & 11.8 & 12.1 & 12.1 & 10.3 & $11.4 \mathrm{a}$ \\
\hline$' 9-8$ ' $\times T$ & 10.2 & 11.0 & 11.3 & 11.7 & 12.0 & 11.9 & 9.8 & $11.1 \mathrm{ab}$ \\
\hline ‘ $9-8$ ’ $\times 0$ & 10.4 & 11.2 & 11.7 & 11.9 & 10.9 & 11.7 & 9.9 & $11.1 \mathrm{ab}$ \\
\hline $99-8$ ' $\times P$ & 10.2 & 10.8 & 11.3 & 12.1 & 11.6 & 12.6 & 10.2 & $11.3 \mathrm{a}$ \\
\hline$T \times P$ & 9.3 & 10.3 & 11.1 & 11.2 & 10.6 & 11.8 & 9.1 & $10.5 \mathrm{c}$ \\
\hline $\operatorname{Mean}^{x}$ & $9.7 \mathrm{~d}$ & $10.6 \mathrm{c}$ & $10.6 \mathrm{c}$ & $11.5 \mathrm{a}$ & $11.1 \mathrm{~b}$ & $11.5 \mathrm{a}$ & $9.5 \mathrm{~d}$ & \\
\hline
\end{tabular}

Leaf temperature was that inside the leaf chamber.

"Mean separation within column (or row) by Duncan's multiple range test, $5 \%$ level. 


\section{Effect of heat stress on photosynthesis, transpira- tion and ion leakage}

Photosynthetic rates of all the parents and their hybrids decreased significantly after being subjected to heat stress (Table 3). Among the parents, the photosynthetic rate of 'Ogon-makuwa' dropped more than $50 \%$ after the first heat stress at $50^{\circ} \mathrm{C}$ for $30 \mathrm{~min}$, and those of 'Thai-7', 'Perlita', and ' $9-8$ ' dropped 42,28 and $16 \%$, respectively (Table 5). For the $F_{1}$ hybrids, the progeny ' $9-8$ ' $\times$ 'Thai- 7 ' was least affected by the stress. Its photosynthetic rate decreased only $4 \%$ whereas those of 'Thai-7' ×'Perlita', '9-8' × 'Ogon-makuwa', and '9-8' $\times$ 'Perlita' decreased by 12,14 and $23 \%$, respectively (Table 5 ). The decrease in photosyn-

Table 3. The effects of high temperature treatments on photosynthetic rate $\left(\mathrm{mgCO}_{2} \cdot \mathrm{dm}^{-2} \cdot \mathrm{hr}^{-1}\right)$ in melons.

\begin{tabular}{|c|c|c|c|c|c|c|}
\hline \multirow{3}{*}{ Variety/cross } & \multicolumn{6}{|c|}{ Date/(Time) $/\left\{\right.$ PAR, $\left.\mu \mathrm{mol} \cdot \mathrm{m}^{-2} \cdot \mathrm{sec}^{-1}\right\}$} \\
\hline & \multicolumn{3}{|c|}{ Before heat treatment } & \multirow[b]{2}{*}{ Mean $^{2}$} & \multicolumn{2}{|c|}{ After heat treatment } \\
\hline & $\begin{array}{c}7 / 10 \\
(11-12) \\
\{1218\}\end{array}$ & $\begin{array}{c}7 / 19 \\
(11 \sim 12) \\
\{1215\}\end{array}$ & $\begin{array}{c}7 / 20 \\
(11 \sim 12) \\
\{1143\}\end{array}$ & & $\begin{array}{c}7 / 21^{y} \\
(12 \sim 13) \\
\{1219\}\end{array}$ & $\begin{array}{c}7 / 24^{x} \\
(12 \sim 13) \\
\{1206\}\end{array}$ \\
\hline ' $9-8$ ' & 26.8 & 26.8 & 25.5 & $26.4 \mathrm{a}$ & $22.2 \mathrm{ab}$ & $22.2 \mathrm{a}$ \\
\hline 'Thai-7' (T) & 19.0 & 21.7 & 20.0 & $20.2 \mathrm{~b}$ & $11.7 \mathrm{~d}$ & $18.0 \mathrm{ab}$ \\
\hline 'Ogon-makuwa' $(0)$ & 25.0 & 20.2 & 22.4 & $22.5 \mathrm{~b}$ & $10.4 \mathrm{~d}$ & $14.6 \mathrm{~b}$ \\
\hline 'Perlita' (P) & 29.0 & 25.3 & 22.5 & $25.6 \mathrm{ab}$ & $18.5 \mathrm{c}$ & $17.8 \mathrm{ab}$ \\
\hline $9-8 \times \mathrm{T}$ & 25.9 & 24.8 & 24.0 & $24.9 \mathrm{ab}$ & $24.0 \mathrm{a}$ & $22.6 \mathrm{a}$ \\
\hline $9-8$ ' $\times 0$ & 27.0 & 23.1 & 24.9 & $25.0 \mathrm{ab}$ & $21.5 \mathrm{ab}$ & $22.2 \mathrm{a}$ \\
\hline$' 9-8$ ' $\times P$ & 26.8 & 25.2 & 25.5 & $25.8 \mathrm{ab}$ & $20.0 \mathrm{~b}$ & $18.4 \mathrm{ab}$ \\
\hline$' \mathrm{~T}^{\prime} \times \mathrm{P}$ & 24.8 & 22.2 & 23.0 & $23.3 \mathrm{ab}$ & $20.6 \mathrm{~b}$ & $15.4 \mathrm{~b}$ \\
\hline Mean & $25.5 \mathrm{a}$ & $23.7 \mathrm{a}$ & $23.5 \mathrm{a}$ & - & $18.6 \mathrm{~b}$ & $18.9 \mathrm{~b}$ \\
\hline
\end{tabular}

Mean separation in the columns and row by Duncan's multiple range test, $5 \%$ level.

${ }^{z}$ Mean of all photosynthetic rates before heat treatment.

y.x The vinyl house was closed to bring the temperature up to $50^{\circ}$ and $48^{\circ} \mathrm{C}$ for 30 and $60 \mathrm{~min}$, respectively, before measuring photosynthesis at normal temperatures, e.g., at $32^{\circ}$ and $31.1^{\circ} \mathrm{C}$.

Table 4. The effects of high temperature treatments on transpiration rate $\left(\mathrm{gH}_{2} \mathrm{O} \cdot \mathrm{dm}^{-2} \cdot \mathrm{hr}^{-1}\right)$ in melons.

\begin{tabular}{|c|c|c|c|c|c|c|}
\hline \multirow{3}{*}{ Variety/cross } & \multicolumn{6}{|c|}{ Date/(Time)/ $\left\{\right.$ Leaf temperature, $\left.{ }^{\circ} \mathrm{C}\right\}$} \\
\hline & \multicolumn{3}{|c|}{ Before heat treatment } & \multirow[b]{2}{*}{ Mean $^{2}$} & \multicolumn{2}{|c|}{ After heat treatment } \\
\hline & $\begin{array}{c}7 / 10 \\
(11 \sim 12) \\
\{30.8\}\end{array}$ & $\begin{array}{c}7 / 19 \\
(11-12) \\
\{31.6\}\end{array}$ & $\begin{array}{c}7 / 20 \\
(11 \sim 12) \\
\{31.3\}\end{array}$ & & $\begin{array}{c}7 / 21^{y} \\
(12-13) \\
\{32.0\}\end{array}$ & $\begin{array}{c}7 / 24^{x} \\
(12-13) \\
\{31.1\}\end{array}$ \\
\hline '9-8' & 8.7 & 10.5 & 10.8 & $10.0 \mathrm{ab}$ & $11.1 \mathrm{c}$ & $10.0 \mathrm{~b}$ \\
\hline 'Thai-7' (T) & 6.7 & 9.7 & 9.8 & $8.7 \mathrm{~b}$ & $10.6 \mathrm{c}$ & $9.2 \mathrm{~b}$ \\
\hline 'Ogon-makuwa' $(\mathrm{O})$ & 11.2 & 10.0 & 11.0 & $10.7 \mathrm{ab}$ & $12.9 \mathrm{ab}$ & $10.7 \mathrm{a}$ \\
\hline 'Perlita' (P) & 11.5 & 11.3 & 11.6 & $11.5 \mathrm{a}$ & $12.2 \mathrm{~b}$ & $11.1 \mathrm{a}$ \\
\hline$' 9-8$ ' $\times T$ & 11.0 & 11.0 & 11.9 & $11.3 \mathrm{ab}$ & $12.7 \mathrm{ab}$ & $11.1 \mathrm{a}$ \\
\hline$' 9-8$ ' $\times 0$ & 11.5 & 11.2 & 11.5 & $11.4 \mathrm{a}$ & $13.0 \mathrm{a}$ & $11.6 \mathrm{a}$ \\
\hline $9-8$ ' $\times P$ & 11.0 & 11.4 & 12.2 & $11.5 \mathrm{a}$ & $12.4 \mathrm{ab}$ & $10.7 \mathrm{a}$ \\
\hline $\mathrm{T} \times \mathrm{P}$ & 10.8 & 10.1 & 11.3 & $10.7 \mathrm{ab}$ & $12.1 \mathrm{~b}$ & $10.7 \mathrm{a}$ \\
\hline Mean & $10.3 c$ & $10.7 \mathrm{bc}$ & $11.3 \mathrm{~b}$ & - & $12.1 \mathrm{a}$ & $10.6 \mathrm{c}$ \\
\hline
\end{tabular}

Mean separation in the columns and row by Duncan's multiple range test, $5 \%$ level.

" Mean of all transpiration rates before heat treatment.

y.x The vinyl house was closed to bring the temperature up to $50^{\circ}$ and $48^{\circ} \mathrm{C}$ for 30 and $60 \mathrm{~min}$, respectively, before measuring transpiration at normal temperatures. 
thetic rate after a short exposure to high temperature was due to an increase in mesophyll resistance to $\mathrm{CO}_{2}$ diffusion (Bar-Tsur et al., 1985; Drake et al., 1970). After the second stress at $48^{\circ} \mathrm{C}$ for $60 \mathrm{~min}$, pohotosynthetic rates of most genotypes were equal to or higher than the rates after the first stress (Table 3). Photosynthetic rates of 'Thai-7', 'Ogon-makuwa', and '9-8' $\times$ 'Ogonmakuwa' were 31,19 and $3 \%$ higher than were those records after the first stress, but that of ' $9-8$ ' remained quite the same (Table 5). Clearly, these genotypes exhibited acclimation to the heat (Drake and Salisbury, 1972; Yarwood, 1962). Further decrease in photosynthesis observed in the other genotypes was probably due to damage to the photosynthetic apparatus (Pearcy et al., 1977). The duration of exposure to high temperatures before acclimation takes place depends on the crops (Heskeh, 1968; Raschke, 1970). Lester (1986) reported that heat acclimation of melon leaves occurs within $24 \mathrm{hr}$, presumably $2-3 \mathrm{hr}$ after exposure to $40^{\circ} \mathrm{C}$. In this study, the temperature in the vinyl house occasionally rose to $40^{\circ} \mathrm{C}$ in the afternoon. Thus temperature acclimation may explain why photosynthetic rates of most genotypes did not drastically drop after the plants were subjected to heat stress.

The transpiration rates of all the parents and their hybrids increased after the first heat treatment (Table 4) probably because the plants were able to absorb more soil moisture while we were in the process of measuring photosynthesis. The second heat stress had no effect on transpiration rates of most genotypes. The transpiration rates of '9-8' × 'Thai-7', 'Perlita', and '9-8' × 'Perlita' decreased 2,3 and $7 \%$, respectively (Table 5 ). As long as the plants do not wilt and the stomata are not closed, transpiration rates will increase as the temperature rises because difference in water vapor pressure within the leaf and ambient air will also increase (Gaastra, 1959; Kramer, 1983).

A conductivity test, based on thermostablity of the plasmalemma, has been used to estimate heat tolerance in beans and other crops (Chen et al., 1982; Martineau et al., 1979). Lester (1985) reported that the threshold temperature for melon leaf membrane leakage was about $40^{\circ} \mathrm{C}$, and that $50^{\circ} \mathrm{C}$ was the approximate inflection point on the temperature curve for $50 \%$ injury to occur. The temperatures used in this study were $48^{\circ}$ and $50^{\circ} \mathrm{C}$, but the electrolyte leakage data obtained did not show $50 \%$ injury and did not correspond well with photosynthetic response to the time of heat stress (Table 6). Ion leakage of all genotypes, except '9-8' $\times$ 'Perlita', did not increase or it increased to less than $50 \%$ of the control after the first heat stress. After the second stress, most genotypes leaked less ions than did those after the first stress. Only 'Thai-7' and 'Ogon-makuwa' had higher ion leakage. Chaisompongpan et al. (1990) also reported that photosynthetic responses of common beans to heat stress did not totally correspond with the ranking of heat acclimation potential obtained by the conductivity test. The poor correlation between the two characteristics was probably due to heat treatments applied to intact

Table 5. Percentage changes in photosynthesis and transpiration in melons after heat stress.

\begin{tabular}{|c|c|c|c|c|c|c|}
\hline \multirow{3}{*}{ Variety/cross } & \multicolumn{3}{|c|}{ Photosynthesis } & \multicolumn{3}{|c|}{ Transpiration } \\
\hline & \multirow{2}{*}{$\begin{array}{l}\text { Before } \\
\text { stress }^{2}\end{array}$} & \multicolumn{2}{|c|}{ After stress ${ }^{y}$} & \multirow{2}{*}{$\begin{array}{l}\text { Before } \\
\text { stress }^{2}\end{array}$} & \multicolumn{2}{|c|}{ After stress ${ }^{y}$} \\
\hline & & $7 / 21$ & $7 / 24$ & & $7 / 21$ & $7 / 24$ \\
\hline '9-8' & 100 & 84 & 84 & 100 & 111 & 100 \\
\hline 'Thai-7' (T) & 100 & 58 & 89 & 100 & 122 & 106 \\
\hline 'Ogon-makuwa' $(0)$ & 100 & 46 & 65 & 100 & 120 & 100 \\
\hline ‘Perlita’ (P) & 100 & 72 & 70 & 100 & 106 & 97 \\
\hline${ }^{\prime} 9-8$ ' $\times T$ & 100 & 96 & 91 & 100 & 112 & 98 \\
\hline ‘ $9-8$ ’ $\times 0$ & 100 & 86 & 89 & 100 & 114 & 102 \\
\hline$' 9-8 ’ \times \mathrm{P}$ & 100 & 77 & 71 & 100 & 108 & 93 \\
\hline $\mathrm{T} \times \mathrm{P}$ & 100 & 88 & 66 & 100 & 113 & 100 \\
\hline Mean & 100 & 77 & 78 & 100 & 115 & 100 \\
\hline
\end{tabular}

${ }^{2}$ The values are the average of data obtained on $7 / 10,7 / 19$, and $7 / 20$ and set to $100 \%$.

y Percentage of the rates before stress. 
leaves and melon plants grown at day temperatures of about $35^{\circ} \mathrm{C}$, and occasionally $40^{\circ} \mathrm{C}$, before the treatments. These treatments probably made the plants acclimated to the heat. Moreover, melon leaves older than 5 days are reported to be less sensitive to heat stress (Lester, 1985).

Since the photosynthetic rates of ' $9-8$ ' and all of its hybrids are less affected by the heat stress, it is likely that this selection has a heritable heattolerance trait.

\section{Relation between photosynthesis and related characteristics}

Varietal differences in the photosynthetic rate and its related traits are presented in Table 7 .

Table 6. The effects of high temperature treatments on ion leakage in melon leaves.

\begin{tabular}{|c|c|c|c|}
\hline \multirow[b]{2}{*}{ Variety/cross } & \multicolumn{3}{|c|}{ Ion leakage $\left(\mathrm{R}_{1} / \mathrm{R}_{2}\right)^{2}$} \\
\hline & $\begin{array}{l}\text { Before } \\
\text { stress }\end{array}$ & $\begin{array}{c}50^{\circ} \mathrm{C} \\
30 \mathrm{~min}\end{array}$ & $\begin{array}{c}48^{\circ} \mathrm{C} \\
60 \mathrm{~min}\end{array}$ \\
\hline '9-8' & 0.14 & 0.17 & 0.13 \\
\hline 'Thai-7' (T) & 0.14 & 0.13 & 0.23 \\
\hline 'Ogon-makuwa' $(\mathrm{O})$ & 0.15 & 0.17 & 0.23 \\
\hline 'Perlita' (P) & 0.22 & 0.25 & 0.15 \\
\hline$' 9-8 ' \times T$ & 0.13 & 0.18 & 0.13 \\
\hline$' 9-8 ' \times 0$ & 0.12 & 0.20 & 0.15 \\
\hline $9-8{ }^{\prime} \times P$ & 0.10 & 0.22 & 0.12 \\
\hline$T \times P$ & 0.17 & 0.17 & 0.12 \\
\hline $\operatorname{LSD}(0.05)$ & 0.05 & 0.08 & 0.05 \\
\hline
\end{tabular}

${ }^{z} R_{1}$; the first conductivity reading. $R_{2}$; the 2 nd conductivity reading taken after the leaf tissue was frozen overnight and thawed, thus releasing the total ions in the tissue.
Only the correlations between photosynthesis and transpiration, leaf chlorophyll as well as nitrogen content were significant. Stomatal and mesophyll resistances are two of several factors governing photosynthetic $\mathrm{CO}_{2}$ influx (Gaastra, 1959). Since the stomatal opening controls $\mathrm{CO}_{2}$ influx and water vapor efflux simultaneously, close correlation between photosynthesis and transpiration is usually observed. In this study, however, the transpiration rates of all genotypes did not decrease after the heat stress, indicating that only mesophyll resistance was increased by the heat (Bar-Tsur et al., 1985; Drake et al., 1970; Gaastra, 1959). Therefore, genotypic differences in photosynthetic rates after heat stress resulted mainly from the differences in mesophyll resistance, i.e., the resistance to $\mathrm{CO}_{2}$ transport between intercellular air spaces and the chloroplast in the mesophyll cells. The inhibition of whole leaf photosynthesis by heat is caused by a functional inactivation of the photosynthetic apparatus at the choloroplast level (Pearcy et al., 1977). Two inactivation scenes exist; that of thylakoid membrane reactions related to photosystem II and that of enzymes related to photosynthetic $\mathrm{CO}_{2}$ reduction metabolism which exist mainly in the stroma of chloroplast (Berry and Bjorkman, 1980). We can not discriminate which is the leading cause of reduction in the photosynthesis of melons in this study. However, it is well established that leaf nitrogen content is strongly correlated with photosynthesis in rice (Makino et al., 1988), and that $75 \sim 85 \%$ of the leaf nitrogen is combined in chloroplast enzymes

Table 7. Varietal differences in photosynthetic rates of melon leaf and the related characteristics.

\begin{tabular}{|c|c|c|c|c|c|c|}
\hline \multirow{2}{*}{ Variety/cross } & \multirow{2}{*}{$\begin{array}{l}\text { Photosynthesis } \\
\mathrm{mgCO}_{2} \cdot \mathrm{dm}^{-2} \cdot \mathrm{hr}^{-1}\end{array}$} & \multirow{2}{*}{$\begin{array}{c}\text { Transpiration } \\
\mathrm{gH}_{2} \mathrm{O} \cdot \mathrm{dm}^{-2} \cdot \mathrm{hr}^{-1}\end{array}$} & \multirow{2}{*}{$\begin{array}{l}\text { Specific dry wt } \\
\mathrm{mg} \cdot \mathrm{dm}^{-2}\end{array}$} & \multirow{2}{*}{$\begin{array}{l}\text { Chlorophyll } \\
\mu \mathrm{g} \cdot \mathrm{dm}^{-2}\end{array}$} & \multicolumn{2}{|c|}{ Nitrogen } \\
\hline & & & & & $\mathrm{mg} \cdot \mathrm{dm}^{-2}$ & $\% \mathrm{dw}$ \\
\hline '9-8' & $26.75 a b^{z}$ & $8.95 \mathrm{~b}$ & $677.28 \mathrm{a}$ & $2710.57 \mathrm{bc}$ & $13.16 \mathrm{a}$ & $1.72 \mathrm{abc}$ \\
\hline 'Thai-7' (T) & $19.00 \mathrm{c}$ & $6.92 \mathrm{c}$ & $478.62 \mathrm{~b}$ & $2262.70 \mathrm{c}$ & $7.22 \mathrm{c}$ & $1.52 \mathrm{abc}$ \\
\hline 'Ogon-makuwa' $(0)$ & $25.00 \mathrm{~b}$ & $11.47 \mathrm{a}$ & $625.26 \mathrm{ab}$ & $2437.47 \mathrm{c}$ & $7.47 \mathrm{c}$ & $1.35 \mathrm{bc}$ \\
\hline 'Perlita' (P) & $28.95 \mathrm{a}$ & $11.77 \mathrm{a}$ & $528.66 \mathrm{ab}$ & $2952.33 \mathrm{abc}$ & $8.23 \mathrm{bc}$ & $1.75 \mathrm{ab}$ \\
\hline$' 9-8$ ' $\times \mathrm{T}$ & $25.85 \mathrm{~b}$ & $11.29 \mathrm{a}$ & $562.63 \mathrm{ab}$ & $2861.77 a b c$ & $7.86 \mathrm{bc}$ & $1.44 \mathrm{abc}$ \\
\hline ‘9-8’ $\times 0$ & $27.00 \mathrm{ab}$ & $11.74 \mathrm{a}$ & $669.85 \mathrm{a}$ & $3227.77 \mathrm{a}$ & $8.87 \mathrm{bc}$ & $1.34 \mathrm{c}$ \\
\hline$' 9-8$ ' $\times P$ & $26.85 \mathrm{ab}$ & $11.26 \mathrm{a}$ & $560.69 \mathrm{ab}$ & $3163.13 \mathrm{a}$ & $9.62 \mathrm{~b}$ & $1.76 \mathrm{a}$ \\
\hline $\mathrm{T} \times \mathrm{P}$ & $24.75 \mathrm{~b}$ & $11.07 \mathrm{a}$ & $566.88 \mathrm{ab}$ & $3150.30 \mathrm{ab}$ & $7.74 \mathrm{bc}$ & $1.38 \mathrm{abc}$ \\
\hline$r$ & & $0.752^{* *}$ & NS & $0.529^{*}$ & $0.521^{*}$ & NS \\
\hline
\end{tabular}

$\mathrm{r}=$ Correlation coefficient between photosynthesis and the other characteristics.

$*, * *$ Significant at the $5 \%$ and $1 \%$, respectively. NS=Nonsignificant.

"Mean separation within column by Duncan's multiple range test, $5 \%$ level. 
(Morita and Kono, 1975). Although no such relationship has been established in melons yet, leaf chlorophyll and nitrogen content, apart from stable and less-reduced photosynthetic rates after heat stress, may be used as indicators in selecting melons with high photosynthetic capacity under high temperature. To establish a conclusive correlation between leaf chlorophyll and nitrogen contents versus heat tolerance in melons, further studies are required, using as many as different cultivars as possible.

\section{Acknowledgements}

The authors are indebted to Professor S. Tokumasu and Professor K. Kadoya for their critical reading of the manuscript.

\section{Literature Cited}

Bar-Tsur, A., J. Rudich and B. Bravdo. 1985. High temperature effects on $\mathrm{CO}_{2}$ gas exchange in heattolerant and sensitive tomatoes. J. Amer. Soc. Hort. Sci. $110: 582-586$.

Berry, J. and O. Bjorkman. 1980. Photosynthetic response and adaptation to temperature in higher plants. Ann. Rev. Plant Physiol. $31:$ 491-543.

Bhattacharya, A., M. Kato and S. Jodo. 1970. Use of male sterility for heterotic effect in $F_{1}$ hybrids of muskmelon (Cucumis meolo L.) Mem. Coll. Agr., Ehime Univ. 15 : 21-31.

Chaisompongpan, N., P.H. Li, D.W. David and A.H. Markhart III. 1990. Photosynthetic responses to heat stress in common bean genotypes differing in heat acclimation potential. Crop Sci. 30:100-104.

Chen, H.H., Z.Y. Zen and P.H. Li. 1982. Adaptability of crop plants to high temperature stress. Crop Sci. $22: 719-725$.

Cooper, P. and T.D. Ho. 1983. Heat shock proteins in maize. Plant Physiol. $71: 215-222$.

Drake, B.G. and F.B. Salisbury. 1972. After effects of low and high temperature pre-treatment on leaf resistance, transpiration and leaf temperature in Xanthium. Plant Physiol. $50: 572-575$.

Drake, B.G., K. Raschke and F.B. Salisbury. 1970. Temperature and transpiration resistance of Xanthi$u m$ leaves as affected by air temperature, humidity, and wind speed. Plant Physiol. 46:314-330.

Fukuyama, T., T. Morimoto, Y. Hashimoto and S. Funada. 1986. Environment control of root system of melon cultivated in a computer-controlled greenhouse. Environ. Control in Biol. 24:9-20. (In Japanese).

Gaastra, P. 1959. Photosynthesis of crop plants as influenced by light, carbon dioxide, temperature, and stomatal diffusion resistance. Meded. Land- bouwhogesch, Wageningen $59: 1-68$.

Heskeh, J.D. 1968. Effects of light and temperature during plant growth on subsequent leaf $\mathrm{CO}_{2}$ assimilation rates under standard conditions. Aust. J. Biol. Sci. $21: 235-241$.

Jodo, S. and M. Kato. 1989. Inheritance of some characters in the breeding process of powdery mildew resistant muskmelon. Mem. Coll. Agr., Ehime Univ. 34 : 81-92. (In Japanese).

Jun, H., K. Suzuki, M. Shibuya, Y. Shinohara and Y. Suzuki. 1986. Effects of high night-temperatures on the growth and yield of tomato cultivars. Abst. Japan. Soc. Hort. Sci., Spring Meeting: 230-231. (In Japanese).

Kadota, T. 1959. Studies on the cardinal temperatures for the root growth of vegetable crop seedlings. Research Reports of the Kochi University 8:1-95.

Kamiya, E. and S. Tamura. 1962. Physiological studies on growing seedling of muskmelon. Bulletin Shizuoka Prefecture Agr. Exp. Stn. $7: 32-44$.

Kramer, P.J. 1983. Water relations of plants. p. 291-341. Academic press, London.

Larcher, W. 1980. Physiological plant ecology. p. 110-121. Springer-verlag, Berlin.

Lester, G.E. 1985. Leaf cell membrane thermostabilities of Cucumis melo. J. Amer. Soc. Hort. Sci. $110: 506-509$.

Lester, G.E. 1986. Physiology of melon leaf membrane thermostability during heat conditioning. J. Amer. Soc. Hort. Sci. $111: 561-564$.

Makino, A., T. Mae and K. Ohira. 1988. Differences between wheat and rice in the enzymic properties of ribulose-1,5-biphosphate carboxylase/oxygenase and the relationship to photosynthetic gas exchange. Planta $174: 30-38$.

Martineau, J.R., J.E. Specht, J.H. Williams and C.Y. Sullivan. 1979. Temperature tolerance in soybean. I. Evaluation of technique for assessing cellular membrane thermostability. Crop Sci. 19:75-78.

Meyer, Y. and Y. Chartier. 1983. Long-lived and shortlived heat-shock proteins in tobacco mesophyll protoplasts. Plant Physiol. 72 : 26-32.

Morita, K. and M. Kono. 1975. Relationship between the changes in the chloroplastic nitrogen fractions and the rate of oxygen evolution in rice plants. Soil Sci. Plant Nutr. $21: 263-271$.

Nybom, N. 1955. The pigment characteristics of chlorophyll mutation in barley. Hereditas $41: 483-498$.

Onwueme, I.C. 1979. Rapid, plant-conserving estimation of heat tolerance in plants. J. Agr. Sci. Camb. $92: 527-536$.

Pearcy, R.W., J.A. Berry and F.C. Fork. 1977. Effects of growth temperature on thermal stability of the photosynthetic apparatus of Atriplex lentiformis. Plant Physiol. $59: 873-878$. 
Raschke, K. 1970. Temerature dependence of $\mathrm{CO}_{2}$ assimilation and stomatal aperture in leaf sections of Zea mays. Planta $91: 336-363$.

Suzuki, E. and S. Masuda. 1961. Studies on muskmelon (Cucumis melo L. var. reticulatus Naud.). V. The fluctuation of sugar content in Earl's Favourite. Bull. Fac. Ed. Sizuoka Univ. 12 : 205-213.

Tai, M. and M. Shannon. 1983. Effects of dehydration and high temperature on the stability of leaf membranes of Lycopersicon esculentum, $L$. cheesmanii, $L$. peruvianum and Solanum pennellii. Z. Pflanzenphysiol. Bd. 112 : 411-416.

Thompson, H.C. and W.C. Kelly. 1957. Vegetable Crops. 5th ed., McGraw-Hill, New York. p. 523-532.

Yarwood, C.E. 1962. Acquired-tolerance of leaves to heat. Science $134: 941-942$.

Whitaker, T.W. and G.N. Davis. 1962. Cucurbits. Interscience Publishers, New York. p. 57-59, 134.

高温下におけるメロンの光合成特性

Niramit Kitroongruang · 上堂秀一郎 - 久井潤也 - 加藤正弘

愛媛大学農学部 790 松山市樽味 3-5-7

\section{摘要}

耐暑性を持つと考えられる9-8 系統を含むメロンの 4 品種・系統と, それらの若干の雑種について，八ウ ス内における光合成と蒸散の日変化を携帯型分析計を 用いて調查した。その結果, 品種・系統間で, 光合成 速度およU゙蒸散速度に有意な差が認められ, 光合成速 度の高い系統は蒸散速度も高い傾向を示した。さらに， 日中の高温時にハウスを締めて $50^{\circ} \mathrm{C} 30$ 分間および $48^{\circ} \mathrm{C} 60$ 分間高温処理を行うと, 各品種・系統とも処理 後の光合成速度が減少した。しかし, 蒸散速度は減少 しなかったので，高温処理による熱ストレスは気孔抵 抗ではなく葉肉抵抗を増加させ, 光合成を低下させた ことが推察された。

$9-8$ 系統およびその雑種では, 高温処理後の光合成
の減少が小さいことから, $9-8$ 系統は耐暑性能力を保 有し，それが遺伝することが立証された。

高温処理に伴う光合成反応とイオン漏出法で判定し た耐暑性とは一致せず，イオン漏出法は耐暑性の判定 に利用し得ないことが分かった。

光合成速度が，蒸散速度，クロロフィル含量および 葉内窒素含量と有意な相関を示すことから，高温処理 後の高い光合成速度とともに，高いクロロフィル含量 および高い葉内窒素含量が，耐暑性メロンの選抜指標 に利用できる可能性が示唆された。なお，指標の有用 性については，品種等の幅を広げて今後とも検討する 必要があろう。 